\title{
American AnTHROPOLOgIST.
}

Vol. VI. WASHINGTON, D. C., JANUARY, $1893 . \quad$ No. 1.

\section{DISTRIBUTION OF GTONE IMPLEMENTS IN THE TIDE- WATER COUNTRY.}

BY W. H. HOLMES.

The tide-water portions of Maryland and Virginia have an area nearly equal to that of the State of Maryland. About one-fourth of the area is occupied by broad arms of the sea, chiefly Chesapeake bay and its tributaries, and the land is a low but handsome plain broken by erosion into hills, valleys, and terraces. It extends inland from the Atlantic seaboard to the base of the highland or Piedmont plateau, which rises on the west to the Allegheny mountains. The curved line separating the two topographic divisionsthe lowland and the highland-is marked by falls in all the rivers and by the location of towns and cities through which pass the great highways of travel connecting the north with the south. Upon this line are located Philadelphia, Havre de Grace, Baltimore, Laurel, Washington, Fredericksburg, Richmond, and Petersburg (see Pl. I). This was the shore-line of the Atlantic when the formations constituting the lowlands were laid down.

The separation of the lowland from the highland is not a topographic separation only, there are pronounced biologic and geologic distinctions, and these combined in archaic times to produce marked anthropologic distinctions. The tide-water region furnished a plentiful supply of game and fish, and in the brackish and salt water areas an abundance of oysters. The natives lived much upon the water and were perhaps more nearly a maritime people than any other group of tribes in the east. Their peculiar biologic environment had a marked influence upon their art, giving it unique forms and exceptional distribution, but their unusual geologic surroundings had a still more pronounced effect upon their 
[Vol. VI.

implements, utensils, and weapons, limiting the forms and sizes and determining to a considerable extent the kinds employed in the various districts independently of biologic and other conditions.

In early historic times the tide-water country was inhabited by numerous tribes of Indians, mainly of Algonquian stock, subject to the renowned Powhatan. A few other nations were located about the headwaters of Chesapeake bay, and others appeared at times along the western and southern borders. The period covered by this occupation practically closed before the middle of the last century. Its beginning is not determined, but cannot extend very many centuries back into the past. Of antecedent or prelistoric peoples, if such there were, we have no information, for the art remains are simple and homogeneous, giving no hint of the occupation of this region by other than the historic tribes. The region is nearly identical with that explored by that intrepid and illustrious adventurer and colonist, John Smith, whose accounts of the natives are among our most valuable contributions to the aboriginal history of the Atlantic States.

The geology of the tide-water country is wholly unlike that of the highland, and the rocks available to the aborigines in the two regions were not only different in distribution but peculiar in the shapes they took and in other features that affect the character of the utensils made and employed. In the highland, west of the dotted line on the map, the varieties of rock occur in massive forms and with definite independent distribution. The workable varieties, such as quartz, quartzite, rhyolite, jasper, and flint, were much sought by the aborigines of the lowland. Fragmental material was to be obtained almost everywhere upon the surface, but choice varieties were confined to limited areas and often to distant regions, and where the surface exposures were not sufficient to supply the demand, quarrying was resorted to and the work of securing, transporting, and trading or exchanging the stone must have become an important factor in the lives of the people. The masses of rock were uncovered, broken up, and tested, the choice pieces were selected and reduced to forms approximating the implements to be made, and in this shape were carried to the lowland.

In the lowland all varieties of hard stones are fragmental and the species are intermingled in varied ways. These fragments of rock are not merely broken angular pieces, such as characterize the surface of the highland, but are rounded masses and bits, known as 


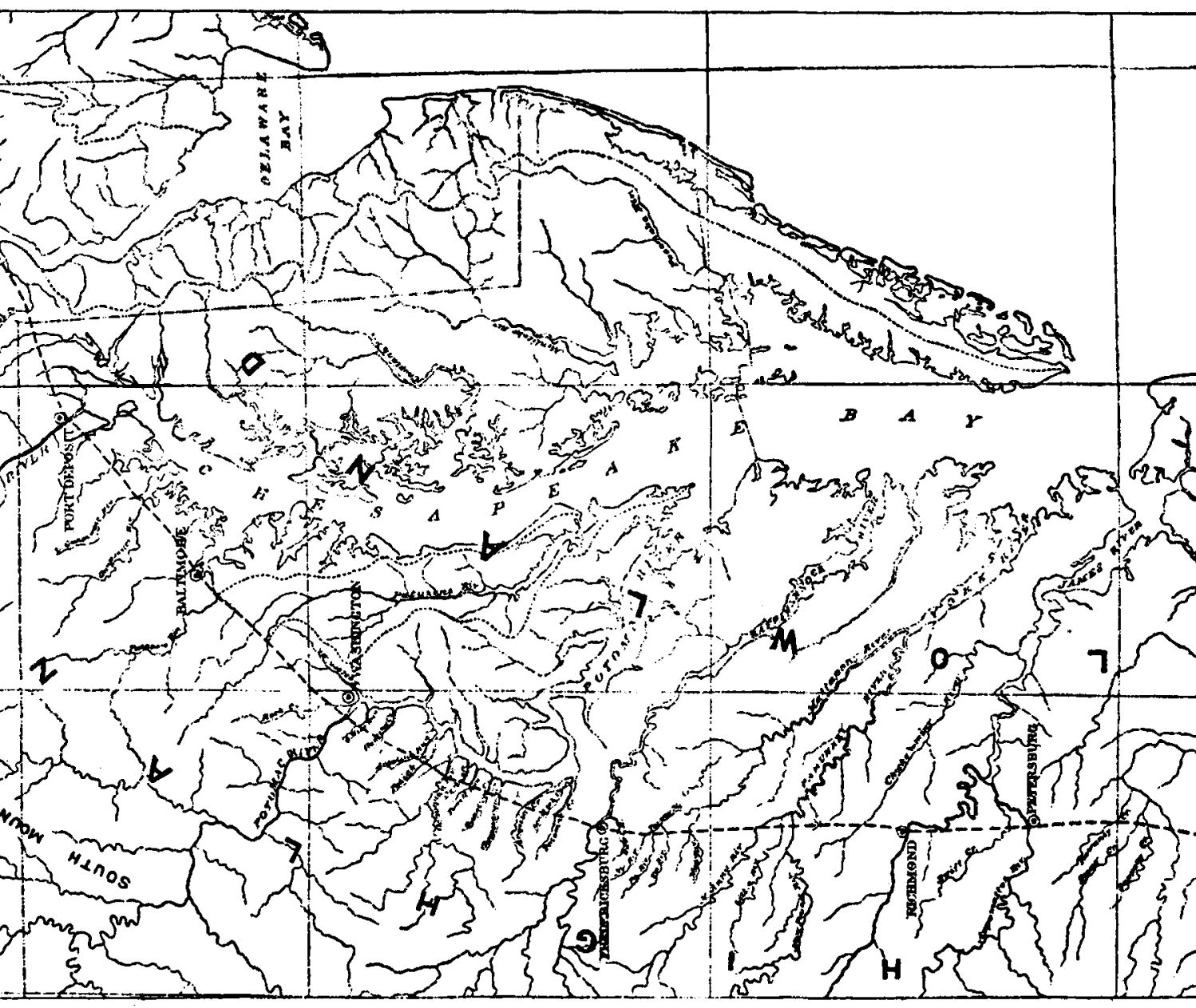


bowlders, cobbles, and pebbles, and comprise chiefly such tough, flinty, homogeneous stones as are available in the arts of primitive men. Nature, in her own way, selected from the highland along the stream courses the very choicest bits of the crumbled rocks, reduced them in hundreds of cataract mills and in the breakers of the sea shore to rounded forms, and deposited them here in the lowlands in great heaps and beds ready to the hand of primitive man.

At first it would seem, to even the keenest observer, that a cobblestone or ovoid bowlder or pebble would be a difficult form of stone to utilize in making knives, spear-points, arrow-points, drills, and scrapers. The smooth rounded mass had to be transformed into a thin blade, every contour of which is incisive or angular. So far apart are the two classes of forms that few people have thought of the bowlder as a prominent source of these objects, but when we look into the matter more carefully we find that nature has not provided any other form or conformation of the several tough varieties of stone so perfectly suited to the purposes of the stone-implement flaker as the bowlder or pebble.

Each river brought down from the highland only such varieties of stone as belonged to the drainage of that river, so that in one valley one set of materials prevails and in another a different set of materials appears, varying with the geologic formations of the region drained. Rivers having identical formations will have nearly identical bowlders. Long rivers crossing numerous formations will have many varieties, short rivers crossing but few will have but a limited number.

There is also a selection as to size by each drainage way. Near the base of the highland, where the force of the current is reduced by meeting tide-water, the larger boivlders are dropped, the smaller ones are deposited farther down, and the pebbles and sand are carried far seaward. Sinall and weak streams transport fewer pieces and drop them sooner. This selection does not hold good with ice transportation, which agency has carried irregular masses of stone to many widely distributed points. Notwithstanding the fact that all water-transported stones are more or less rounded, there is a selection with respect to degree of roundness. If dropped early in the progress of transportation the bowlder is imperfectly rounded; if carried far, it is fully rounded. Near the margin of the highland, therefore, there is a large percentage of imperfectly rounded stones, and farther out there is a small percentage of irregular forms. 
These conditions are probably considerably modified by the action of the waves along the ancient sea-shore which skirted the base of the highland. Such fragments as were subjected to wave action became fully rounded and were deposited in beds along the ancient beach lines. It is not easy to distinguish the beach-rolled material from that rounded by the flow of streams, both agencies having, no doubt, frequently acted in turn upon the same material.

Again we observe that on river banks near the base of the highland many varieties of rock are present, but with each mile as we descend the number is diminished, the softer species are reduced to sand as they move toward the sea and one after another disappears. Quartz, being the hardest, is last to yield to the erosive agents, and at various points along the ocean beach well-polished quartz pebbles are found.

A comparison of the Potomac and Patuxent rivers, with respect to these points, is instructive. In ancient times both streams as they descended from the mountains gathered fragments of rock and carried them downward until the soft and friable ones were reduced to sand and the tough, flinty varieties became bowlders and pebbles. The latter consisted chiefly of quartz and quarzite. The Potomac was a long stream, heading far to the west and cutting through many ranges of mountains and hills. It crossed heavy beds of quartzite in the region of Harper's Ferry. This rock is tough and massive and breaks up into rather large fragments; thus it is we have many large quartzite bowlders deposited in the valley about Washington and below, the sizes diminishing toward the sea. Between Harper's Ferry and Washington the river crosses a belt of gneissic rocks intersected by many veins of quartz. This latter rock is hard and brittle and breaks up into small fragments, which, when rounded, are usually of the size denominated pebbles. These were taken up by the waters in countless numbers and distributed with the quartzite bowlders from Washington to the sea; but the quartz is harder than the quartzite and resisted the erosive agents more successfully, so that after the quartzite disappears there are still quartz pebbles in plenty.

The other stream, the Patuxent, has a limited drainage and does not cross the quartzite belt, but drains the quartz-bearing belt. Below the point of its entrance into the tide-water country at Laurel we find of the flakable stones chiefly quartz in small fragments; lower down all are well rounded, forming pebbly gravels. 
It is thus seen that nature has selected the rocks used by the tidewater peoples and has distributed them in groups varying with original location, with hardness, with toughness, with shape, and with size.

The effect of these conditions of distribution upon the stone art of the various districts was necessarily very pronounced. One community located conveniently to deposits of large bowlders used large stones, and the tools shaped from them average large. Another community located in a pebble-bearing district utilized pebbles, so far as they were capable of utilization, and this people had few large tools and many small ones, the average size being very small. Dwellers in quartzite-bearing districts had quartzite tools; those having quartz deposits had quartz tools, and those residing near the base of the highland had many varieties of stone, and hence used a much greater diversity of stone tools, since the working qualities or capacities of each stone varies from the rest.

As a result of these conditions the tide-water Potomac is rich in chipped tools both of quartzite and quartz of home production. The Patuxent yields a large percentage of quartz tools, most of which are native. The Potomac yields to the collector a large percentage of large tools; the Patuxent a large percentage of small ones. These remarks relate to the native varieties of material and implements made from them. Exotic materials had their own peculiar distribution, which will be examined farther on.

Nearly all rude, bulky implements of chipped stone and all failures or rejects of manufacture are, as a matter of course, found upon or near the sites from which the raw materials were derived. Rejects are large and clumsy on the upper tide-water Potomac, because of the large size of the bowlders available. They are small on the Patuxent, because the pebbles utilized were small.

Again, the percentage of the failures-the turtle backs and other refuse of manufacture-decreases rapidly with the distance from the source of supply of the raw material, extending little beyond it. This may be illustrated. In the vicinity of Washington we have a great deposit of quartzite bowlders. In Fig. I the dotted line may be taken as roughly indicating the workable bowlder-bearing area. and the angular markings show the distribution of rejects of manufacture. The successful blades and the finished tools produced would radiate much more widely, but would also diminish with distance from the source of supply,.as indicated by the small strokes 
in Fig. 2. Favorite routes of travel would receive the fuller supply of these objects, and dwelling and important hunting and fishing sites would have large supplies, as indicated by "village site" in Fig. 2. On the source of supply of the raw material failures and finished implements or rejects would exceed finished implements in numbers, but beyond this the latter are almost wholly prevalent. So-called paleolithic forms-the rejects of manufacture-are thus confined to limited areas, the areas producing the raw material; and it is easy to see how in various sections of the country before

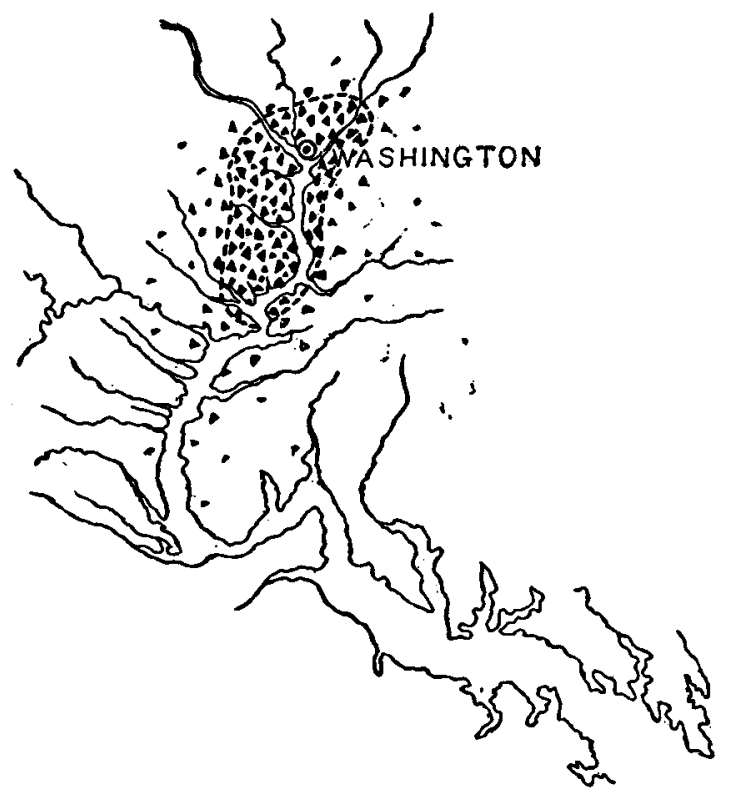

FIG. 1.-Distribution of rejects of manufacture with respect to distribution of raw material.

the true nature of these forms was known certain localities were thought to have been especially favored by paleolithic man.

It would thus appear from what has been said that the artificial distribution of materials is limited by-is a modification of-the natural distribution, and that each class of artificial object is scattered in a way peculiar to itself; but the human agent is an important factor. Other things being equal, human distribution of small things is far, of large objects near; implements of war and 
the chase travel far, domestic utensils remain near; improvised articles or devices are near, highly elaborated and valuable objects go far; with thoroughfares distribution is far, across thoroughfares it is near. Much-occupied sites are richly stocked with utensils, and slightly occupied spots have but few; sites near the source or sources of supply have a wealth of art, very distant ones have almost nothing; sites convenient to a plentiful supply of one material have many tools of that material, sites remote from any of

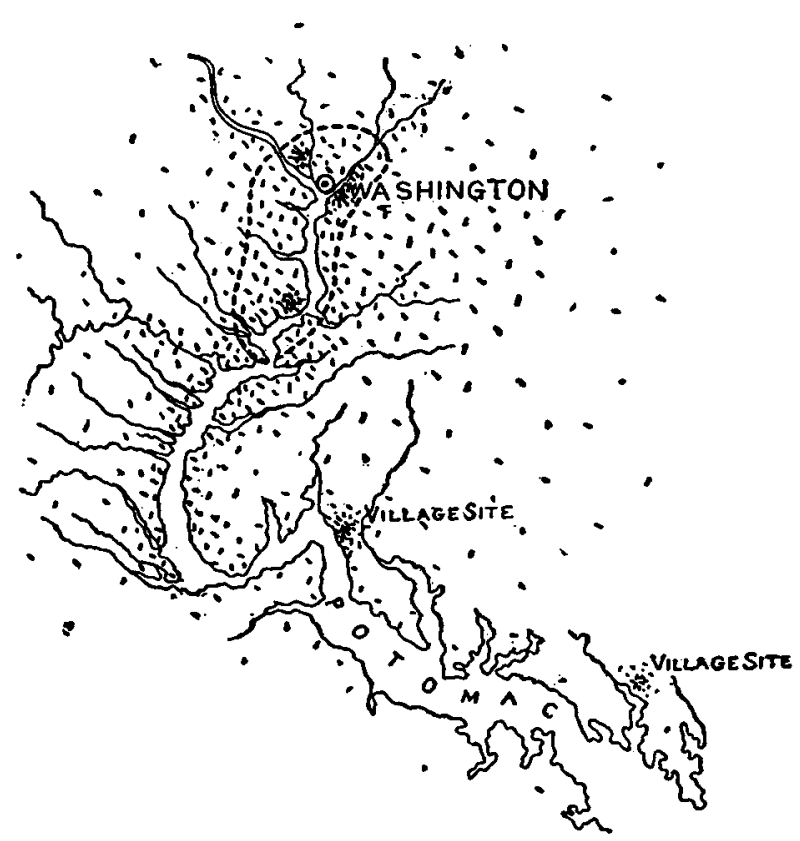

FIG. 2.-Distribution of implements with respect to distribution of raw material.

the sources have a limited supply from many sources. A sedentary people will not distribute. widely; wandering or semi-sedentary tribes will transport their possessions to many distant places, and sites occupied by numerous tribes in turn will have diversified art remains. It may be further noted that on sites devoted to single or simple industries the range of tools will be small and on sites where occupations were varied the range will be large, and that 
where peoples were varied, occupations varied, materials varied, and time long we will have the widest range.

The tide-water peoples were by no means content with the materials supplied by the province in which they lived, although these naturally received first attention. Not being favored by nature in the quality and range of their materials, they seem to have searched far and near for those finer-grained homogeneous varieties so much used in other regions. They sought flint in the mountains of Virginia fully a hundred miles beyond the tide-water limit; they discovered a slaty-appearing volcanic porphyry, called rhyolite, in South mountain, 75 miles northwest of Washington, and jasper and argillite were obtained from eastern and northeastern Pennsylvania. It is probable that in some cases the tide-water peoples made long journeys in search of these rocks and spent short seasons quarrying and roughing out the blank forms and selecting choice bits to be carried home. On the other hand, much of the material from these distant places may have reached the lowland by exchange or trade, and a certain amount, not ascertainable, of the supply of implements of exotic materials is no doubt due to visits and incursions by peoples occupying the region of the source of supply; for example, jasper may have been brought by the Susquehannocks of the north, and flint by the Monacans of the west. It may be that in time, by careful comparison of the forms of implements characterizing the various exotic materials, something may be suggested of the presence of neighboring peoples in or at least of their influence upon the art of the tide-water region. Distribution is very general, implements made of all of the varieties of stone mentioned being scattered more or less fully over the Chesapeake-Potomac country as far south as James river.

Jasper, the quarries of which have recently been located by Mr. H. C. Mercer, of Philadelphia, is more plentiful in the upper Chesapeake and Susquehanna regions. Argillite, which was obtained in the Delaware valley, did not find its way to any great extent into Maryland and Virginia, although several caches of blades have been discovered in the middle Chesapeake region, and implements are occasionally found. Rhyolite implements are most plentiful in the Patuxent and Potomac valleys, and especially in those portions of them adjoining South mountain. The quarries of this stone are in Pennsylvania, near the head of the Monocacy, and the implements are very numerous on that stream, and fragments of considerable size have been carried far down the Potomac. 
Transportation was no doubt mainly by water. Probably onefourth of the spear and arrow points of the Potomac region are made of this rock. Flint of a dark or blackish hue was used in making smaller projectile points, as were also quartz and jasper. These materials, breaking naturally into small pieces, were not well fitted for the making of large implements.

It should be noted that of these exotic materials we have in the tide-water country very few large or rude implements, and, as a matter of course, failures of manufacture are rare, save those that result from breakage during such specializing and finishing operations as were conducted subsequently to transportation from the quarry. Of quartz and quartzite, the native flakable stones, there are countless rejects of manufacture of all grades, as previously described.

It may be said of quartzite and quartz that a portion of these materials-perhaps a large portion, especially of the latter-were secured from the highland beyond the tide-water limit, and no one can say from the examination of ordinary finished implements of these materials whether or not they were made from a native bowlder or from a foreign mass or flake; but the presence of countless numbers of the rejects of manufacture from quartz and quartzite bowlders and pebbles within the tide-water area, and the rarity, so far as I have been able to discover, of refuse of manufacture in the highland, seem to make the true conditions clear.

Cut, pecked, ground, and polished implements of usual types are common in this region. Soapstone, used in making pots, pipes, sinkers, and ornaments, was quarried in hundreds of places along the eastern border of the highland. The unfinished objects are found on the quarry sites and upon dwelling sites near by. The finished utensils and implements are scattered far and wide, but grow less plentiful as we approach the Atlantic coast. The picks and chisels used in working the soapstone are confined to the quarries and their vicinity.

Axes, celts, and the like were made for the most part of tough bowlders of volcanic and granitic rocks obtained from the streambeds or from the highland. Failures resulting from the manufacture of these implements are frequently found upon village sites along the banks of the larger streams. Rejection or failure was not uncommon even after the pecking operations began, and breakage under the pecking hammer was not rare. It is important to observe 
that in many cases these implements were reduced to approximate shape by flaking, and this has given rise to several classes of flaked rejects, peculiar in shape and exceptional in material. These objects are of such rude forms that they are sometimes mistaken for very primitive implements, thus providing another trap for the unwary paleolith hunter.

The liability of the various stone implements of the tide-water region to transportation is approximately expressed in the following partial list. Beginning with those least subject to transportation and ending with those most subject to it, we have the following tentative order:

Morlars, generally improvised from bowlders having at least one concave surface which was gradually deepened by use. They were probably rarely far removed from the site of their first utilization. Many improvised tools and utensils, mullers, pestles, hammerstones, etc., were equally home-stayers, as they were merely natural shapes picked up and adapted to the needs of an occasion.

Sharpened bowliters, improvised chopping or bone-breaking tools, occur on all river sites where bowlders were at hand. The edge or point was made by removing one or more flakes. They were not transported far beyond the limits of the bowlder-producing area.

Notched and sharpened bowlders, improvised axes, picks, or hoes, closely related to the preceding, but intended to be hafted. Their transportation was but slight, as they are rarely found beyond the range of deposits of heavy bowlders. Half a dozen blows with a hammer-stone were sufficient to fashion one of these objects.

Picks and chisels for working soapstone traveled but little beyond the quarries and the neighboring villages where the finishing was done. These consist of rude, sharp stones, of axes and celts worked over or "upset" to secure good points, and of thick leafshaped chisels reduced to approximate shape by flaking and then ground to an edge at one or both ends.

Net sinkers are not common and are usually rude. They were probably carried back and forth to some extent along the streams.

Pestles, cylindrical stones symmetrically shaped and well finished by pecking, were apparently carried from place to place and perhaps for long distances.

Hammer-stones: Many of these objects were improvised from bowlders and were quickly cast aside, as already indicated, but others were carried far out into the non-bowlder-bearing region, where they acquired by use or were given purely artificial contours. 
Soapstone vessels are widely distributed, reaching in rather rare cases points roo miles or more from the highland in which the material was quarried.

Grooved axes, celts, scrapers, drills, knives, spear-points, arrowboints, as well as pipes and ornaments, were freely transported, covering the full range of the peoples employing them, and not infrequently, no doubt, passing from district to district through other hands.

Rejects resulting from failures in specialization of transported forms and from attempts at remodelling of worn or broken tools are to be found everywhere, but rejects of the roughing-out processes are not seriously affected by the transporting agencies, remaining mainly upon the shop sites.

Some of the eccentricities of distribution may be illustrated by examples, sites having varying relations to the deposits of raw material being chosen for the purpose, as follows :

I. On a site of quarrying and manufacture where dwelling was inconvenient, as on the bluffs of Rock creek, the work was confined mainly to roughing out leaf-shaped blades, and the series of art forms comprise a limited range, including turtle-backs and other kinds of rejects and refuse. Nothing exotic, nothing finished, nothing that might not readily be classed as "paleolithic" by our American advocates of the idea of a rude stone age, was found in three months' work upon the shop sites of Rock creek.

2. On a site of quarrying and manufacture where dwelling was practicable and where lodges were actually pitched to a limited extent, we find intermingled with the rude forms some specialized ones and a few tools of exotic origin, such as projectile points of rhyolite and axes and celts, as at Riggs' mill, eight miles northeast of Washington.

3. On a site of manufacture and at the same time of extensive dwelling, as at Anacostia, D. C., where much raw material was at hand, all varieties of refuse and of rude forms are found; likewise well-shaped and wholly-finished specimens of flaked tools of local origin prevail. There are also all the cut, pecked, and polished tools and ornaments common to village sites. Besides these, many exotic materials in varied forms are found.

4. On a village site where no raw material, save small quartz pebbles, is found there will be a full range of small quartz rejects and of small quartz implements, with a liberal supply of finished implements of exotic materials averaging small. 
5. On a site remote from all sources of raw material, as on the eastern shore, the objects average small and are much varied in material and style, having come far, through numerous peoples and from many sources.

Typical illustrations of the two last-mentioned varieties of sites are difficult to find, for the reason that in all sections, even far out toward the present ocean beach, there are occasional ice-borne bowlders and fragments of considerable size, and these were collected by the natives and used for mortars, mullers, and for various flaked and pecked implements, and such objects destroy the entire simplicity of conditions conceived for the sites described.

A synoptical statement is made in the accompanying plate (Pl. II) which exhibits many of the most striking features of the flaked-stone archeology of this province, and indicates clearly the points most requiring attention in other regions. The stories of the origin and form of the materials, of manufacture, rejection, elaboration, transportation, storage, specialization, and use are all expressed or suggested. Four materials are represented, two native, in the form of bowlders, and two exclusively exotic and derived from mass deposits. Each series indicates the course of development through which most of the finished forms passed betiveen the first stroke given to the shapeless stone and the finished work of art.

In the first and second series all the forms, from the bowlder to the most minute art shapes, are represented in solid lines, being exclusively tide-water art. Nos. I, 2, 3, 4, 5 and 6 are shop rejects, turtle-backs, etc., and are not implements. Nos. 7,8 and 9 are roughed-out forms, blanks, blades ready for further specialization, and are not necessarily implements, although they were available as knives and scrapers. The numbers from 10 to 18 are specialized forms derived mainly, no doubt, from bowlders, and include knives, spear-points, arrow-points, and perforators or drills.

The second series comprises forms derived mainly from quartz pebbles, and which are naturally smaller than the quartzite forms. They are drawn in solid lines, being of native derivation. Nos. 1 , $2,3,4,5,6$ and 7 are shop rejects, turtle-backs, and are not implements. No. 8 is a profile, showing the ordinary "peak" or hump of the reject. Nos. 9, ro and I I are successful blades, which may have been employed as knives or scrapers, but were usually intended for specialization into arrow-points, spear-points, perforators, etc., as indicated in Nos. 12 to 20.

The third series, consisting of objects of rhyolite, is drawn 
partly in solid lines and partly in dotted outlines. Those in solid lines comprise transported and specialized objects and were collected in the tide-water country. Those in dotted lines $a, b, c, d$, $\epsilon$ and $f$ are the rejects of manufacture and are not found in the tide-water country, being obtained only on the quarry-shop sites in Adams county, Pennsylvania. The successful blades, illustrated in $g, h$ and $i$, were carried away from the quarry to be used as they are or for specialization when the succeeding forms, $j$ to $q$, were needed. The whole tide-water province is abundantly supplied with all the forms from $g$ to $q$.

The fourth series, composed of articles of jasper, repeats very closely the conditions of the third or rhyolite series. The sizes average smaller on account of the minuter cleavage and inferior massiveness of the rock. The rejects of manufacture, indicated in dotted lines, are obtained mainly from the recently discovered quarries in eastern Pennsylvania. Other quarries may yet be found, and some of our rivers furnish occasional bits and pebbles of this material. The cache and finished objects, $g$ to $q$, are widely scattered over the tide-water region.

Stone implements have been studied as to form, material, and use, but there has been no systematic study of manufacture, and origin and distribution have been greatly overlooked. It is of the utmost importance that in taking up the stone implements of a region each leading material be traced back to its source, so that from this point of view a study can be made of the work of quarrying, shaping, transporting, and finishing. Each form or class of implement will thus be found to have left in its wake a trail of "wasters" or rejects peculiar to itself. Until these are understood, selected, and set apart there is necessarily much confusion.

It is seen by a study of PI. II that a half or more of the native flaked forms of this region are actually not implements. The separation is approximately indicated by the upper braces marked "not implements" and "implements." It will be observed that this division separates the cache forms or blanks of the middle column into two parts. Portions of this class of objects were mere quarry shapes distributed to be elaborated when needed, but some of them were probably utilized in their blank shape as knives, etc., and some show a slight degree of specialization, as in No. $g$ of the first series, and thus properly take their place with implements. Nearly all of the specimens shown in this vertical column are actual cache finds. 
This study brings out other features of flaked-stone art which have not been understood and have thus given rise to much embarrassment and to much useless discussion on the part of those who have been talking of rejects as implements. Each material gives different forms of rejects. Each form of material gives its own styles of rejects. Each implement leaves its own peculiar rejects. If in the tide-water country six varieties of stone were used in the manufacture of flaked implements, if two of these materials occur in distinct forms and if one of them was employed in making two distinct types of implements, then there would be found here ten lines of refuse or "wasters," each furnishing its own peculiar types of rude forms. Several of these genetic lines have already been, as illustrated in Pl. II, more or less fully traced and the rejects separated from the implements. In other sections of America and in certain provinces of Europe there may be many more than ten distinct evolutionary series, and in Europe so many centuries and successive culture periods have passed and so much has been obliterated by thousands of years of metal-age occupation that the phenomena there must be both complex and obscure. It is plain, therefore, that if the European students of rude flaked stones have not been more discriminating than most of their pupils in this country, there is still work to be done there.

The distribution of cut, pecked, ground, and polished stone implements, and the refuse of their manufacture, is governed by laws similar to those governing the distribution of flaked stone.

Each province, district, and site, here and elsewhere, is supplied with art remains brought together by the various agencies of environment-topographic, geologic, biologic, and ethnic-and the action of these agencies is to a large extent susceptible of analysis, and this analysis, properly conducted, constitutes a very large part of the science of prehistoric archeology.

It would be instructive to examine in this place, so far as is possible, the effect of the distribution of the various kinds and forms of stone upon the habits, customs, arts, industries, etc., of the inhabitants of the region, for it is plain that so important an element of environment must have a most decided influence upon all departments of culture, but such a study would carry me far beyond the limits set for this sketch; besides, such a work can be conducted to better advantage where all the phenomena of human existence are observable as with living tribes, and the laws of culture evolution thus derived are applicable to all cases and fully answer the needs of anthropology. 
This synoptical grouping of the ordinary varieties of flaked stoues found in the tide-water country will, in a great measure, serve as a key to the whole subject of flaked stone art in eastern North America, and will suggest a practical method of treatment for all sections. Varieties of flaked implements not included in this series are of rare or exceptional occurrence or belong to what $I$ have designated extemporized tools

Specimens drawn in solid lines are obtained from the tide-water region. Those in dotted lines are not found, save in rare cases, within that region, having been left as refuse in the quarries in Pennsylvania from fifty to two hundred and fifty miles away.

The two upper lines have their genesis mainly in bowlders and pebbles ; the lower lines are derived from materials quarried from the mass. The left-hand vertical column contains usual forms of failures, rejected in most cases on account of defective fracture which resulted in too great thickness, thinness being essential. Our so-called "paleolithic implements" belong in this column.

The middle column contains blades derived as indicated in the lefthand column. They were carried away from the quarries and shops to be used as they are or to be further elaborated. They are often found in caches or hoards where they were left by owners or traders. Some are slightly specialized, as $q$ in the first line and $i$ in the third line.

Quarry products at the transportation stage are necessarily not uniform in character. The blades, etc., accepted and carried away at one time may be ruder or less finished than those accepted and carried away at another time. In the third line, $f$, a reject from the quarry refuse may be more refined in shape than the transported and cached form $g$. Transporting and caching of raw material on the one hand and of finished implements on the other are not unkuown, but caching was mainly the result of transporting and storing of roughed out implements in quantities not at once needed, and this was usually due no doubt to the intermittent nature of quarry production.

The right-hand column contains series of specialized forms, arrowpoints, spear-points, knives, drills, etc., derived in the main as indicated in the genetic series. The smaller points were often made, no doubt, from small fragments or chips, but the process was essentially the same.

The process employed in roughing out and in the earlier stages of specialization was that of free-hand percussion with hammer-stones. The finishing was probably mainly by pressure with tools of bone.

The grouping as indicated by the braces should be carefuily stidied. 


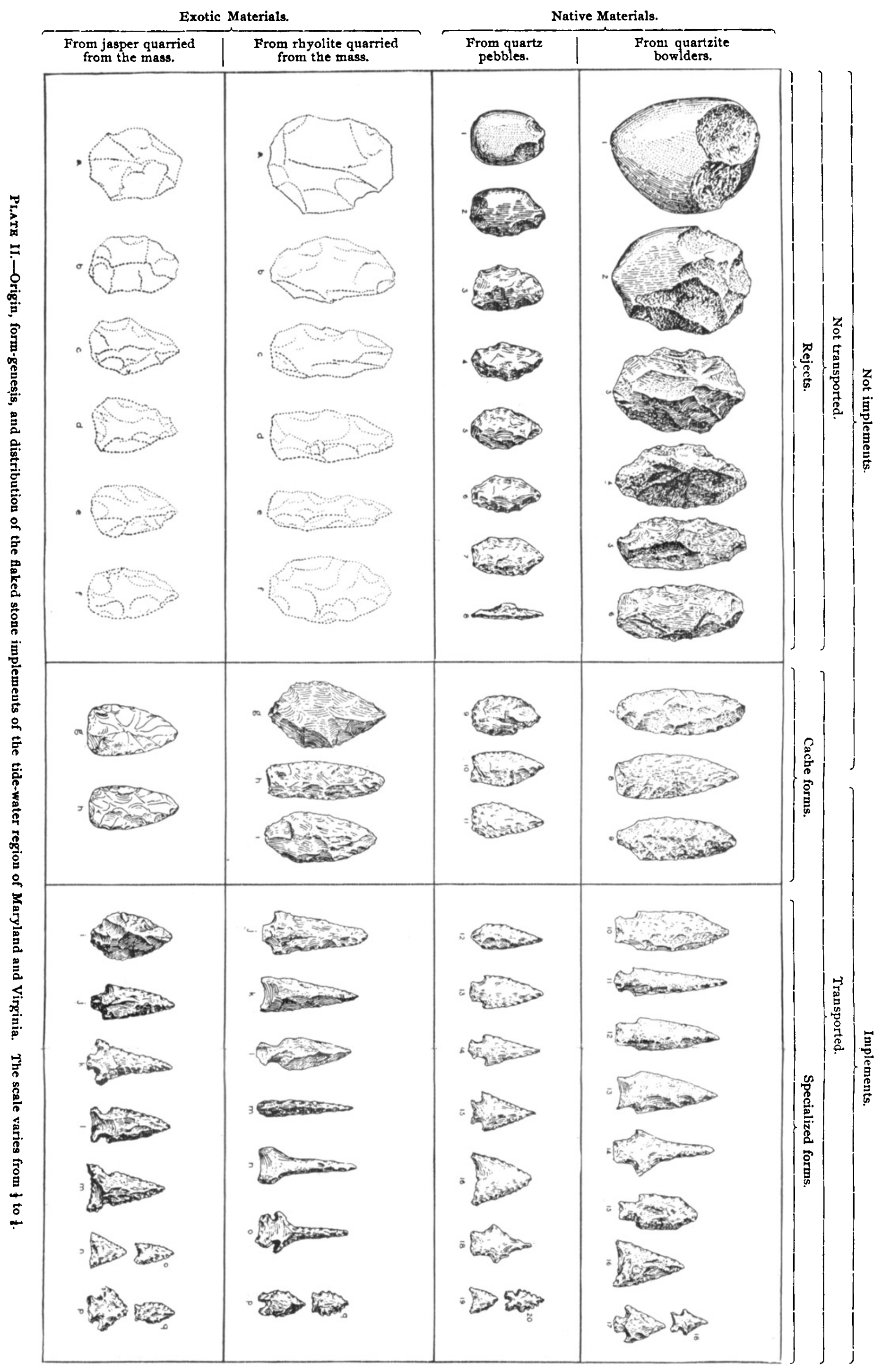

